\title{
27. GEOCHEMISTRY OF HYDRATE GAS AND WATER FROM SITE 570, DEEP SEA DRILLING PROJECT LEG 841
}

\author{
James M. Brooks, Alan W. A. Jeffrey, Thomas J. McDonald, and Ronald C. Pflaum, Department of \\ Oceanography, Texas A\&M University \\ and \\ Keith A. Kvenvolden, U.S. Geological Survey²
}

\begin{abstract}
Molecular and isotopic measurements of gas and water obtained from a gas hydrate at Site 570, DSDP Leg 84, are reported. The hydrate appeared to be Structure I and was composed of a solid framework of water molecules enclosing methane and small amounts of ethane and carbon dioxide. Carbon isotopic values for the hydrate-bound methane, ethane, and carbon dioxide were -41 to about $-44,-27$, and $-2.9 \%$, respectively. The $\delta^{13} C_{C_{1}}$ values are consistent with void gas values that were determined to have a biogenic source. A significant thermogenic source was discounted because of high $\mathrm{C}_{1} / \mathrm{C}_{2}$ ratios and because the $\delta^{13} \mathrm{CCO}_{2}$ values in these sections were also anomalously heavy (or more positive) isotopically, suggesting that the methane was formed biogenically by reduction of heavy $\mathrm{CO}_{2}$. The isotopically heavy hydrate $\delta^{13} \mathrm{CC}_{2}$ is also similar to void gas isotopic compositions and is either a result of low-temperature diagenesis producing heavy $\mathrm{C}_{2}$ in these immature sediment sections or upward migration of deeper thermogenic gas. The salinity of the hydrate water was $2.6 \%$ with $\delta \mathrm{DH}_{2} \mathrm{O}$ and $\delta^{18} \mathrm{OH}_{2} \mathrm{O}$ values of +1 and $+2.2 \%$, respectively.
\end{abstract}

\section{INTRODUCTION}

Gas hydrates are solid, icelike clathrate structures in which gases are included within a crystalline water lattice under appropriate conditions of high pressure and low temperature. Gas hydrates exist in two forms: Structure I hydrate has a symmetric shape and can include small molecules up to the size of ethane $\left(C_{2}\right)$. Structure II hydrate is slightly larger and has the ability to accommodate not only methane $\left(C_{1}\right)$ and $C_{2}$, but also propane $\left(\mathrm{C}_{3}\right)$ and isobutane $\left(i-\mathrm{C}_{4}\right)$. Molecules as large as or larger than $n$-butane $\left(n-\mathrm{C}_{4}\right)$ cannot be included in either lattice type (Davidson et al., 1978) because cages within the lattice are too small. The stability conditions for gas hydrates in marine sediments are generally found in slope regions at water depths greater than $\sim 500 \mathrm{~m}$ and having bottom-water temperatures near $0^{\circ} \mathrm{C}$. Although a wide range of molecules (e.g., $\mathrm{C}_{1}, \mathrm{CO}_{2}, \mathrm{~N}_{2}, \mathrm{O}_{2}, \mathrm{H}_{2} \mathrm{~S}, \mathrm{C}_{2} \rightarrow i$ $\mathrm{C}_{4}$ hydrocarbons) can form hydrates, $\mathrm{C}_{1}$ and possibly $\mathrm{CO}_{2}$ are the only gases found in sufficient quantity to form gas hydrates in deep sea sediments. Under the appropriate pressure and temperature conditions for hydrate stability, gas concentrations must exceed solubility levels at the in situ temperatures and pressures before hydrates can form. Therefore, gas hydrates can only be found in regions where there is significant biogenic methane generation or where there is migration of thermogenic gases from deeper horizons. Thermogenic gases do not form hydrates at their sites of generation because the temperatures necessary for thermogenic gas forma-

\footnotetext{
${ }^{1}$ von Huene, R., Aubouin, 1., et al., Init. Repts. DSDP, 84: Washington (U.S. Govt. Printing Office).

2 Addresses: (Brooks, Jeffrey, McDonald, Pflaum) Department of Oceanography, Texas A\&M University, College Station, TX 77843; (Kvenvolden) U.S. Geological Survey, Menlo
} Park, CA 94025. tion are higher than those within the zone of hydrate stability.

The presence of gas hydrates has been suspected in marine sediments for many years because of evidence from laboratory stability studies and because of the existence on some marine seismic records of a bottom-simulating reflector (BSR). A BSR is an anomalous acoustic reflector that approximately parallels the bottom topography and that cuts across bedding planes and deepens with increasing water depth (Shipley et al., 1979). The BSR is thought to represent the lower boundary of the gas hydrate stability zone, below which gas hydrates decompose due to increasing temperature with depth. There are many areas of the world's oceans where hydrates have been inferred on the basis of seismic records (Kvenvolden and McMenamin, 1980; Kvenvolden and Barnard, 1983a). Gas hydrates appear to be common in the continental margins of all the world's oceans. However, prior to DSDP Leg 84, gas hydrates had been directly observed in marine sediments only (1) in shallow cores of the Black Sea (Yefremova and Zhizhchenko, 1974), (2) at $238 \mathrm{~m}$ sub-bottom on Leg 76 in the Blake Outer Ridge of the Atlantic (Kvenvolden and Barnard, 1983b; Brooks et al., 1983), and (3) on Legs 66 and 67 in the Middle America Trench off Mexico and Guatemala (Moore et al., 1979; von Huene, Aubouin, et al., 1980). Because hydrates are not stable at atmospheric pressure, even at $-20^{\circ} \mathrm{C}$, no samples of gas hydrates had been collected for shore-based laboratory studies from the occurrences just mentioned. Now samples of gas hydrate have been collected from Site 570 on Leg 84 for shore-based analyses, some of which are reported here. Subsequent to Leg 84 , gas hydrates had been collected from surficial cores at a water depth of about $530 \mathrm{~m}$ in the northwest Gulf of Mexico and had been analyzed on shore (Brooks et al., 1984). 


\section{METHODS}

Samples of gas hydrate from Site 570 of Leg 84 were obtained for analysis as (1) specimens of hydrate collected on board ship and inserted into and sealed in stainless steel pressure cylinders; (2) shipboard aliquots from hydrate sealed in a Parr pressure bomb equipped with a gauge and sampling port; and (3) laboratory aliquots of hydrate maintained at the Colorado School of Mines in pressurized containers at reduced temperatures (Sloan, this volume). Samples from the Parr bomb were taken after hydrate decomposition in a $23-\mathrm{cm}^{3}$ sample holder (see Kvenvolden et al., 1983 for details). Samples from the gas hydrate recovered at Site 570 that was stored in a pressure container at reduced temperature were subsampled at the Colorado School of Mines in December 1982. The samples were inserted into $300-\mathrm{cm}^{3}$ stainless steel cylinders, which was sealed, and they were then allowed to decompose. Shipboard specimens were sampled in a similar manner.

For stable carbon isotopic analysis, $C_{1}$ was separated from the other gaseous components by fractional distillation at liquid nitrogen temperature and combusted to $\mathrm{CO}_{2}$ in a system similar to that described by Sackett et al. (1970). $\mathrm{CO}_{2}, \mathrm{C}_{2}$, and higher hydrocarbons were separated using a Carle Model 8000 gas chromatograph equipped with a silica gel column, and individual components were isolated in traps packed with Porapak Q adsorbant at liquid nitrogen temperature. The individual hydrocarbons were combusted to $\mathrm{CO}_{2}$ in the same system used for $\mathrm{C}_{1}$. Isotopic analysis of $\mathrm{CO}_{2}$ was performed on a Nuclide RMS 60 ratio mass spectrometer, and the results were reported relative to the PDB standard. Precision on replicate samples was generally better than $\pm 0.2 \%$.

Hydrocarbon compositions were determined on a Hewlett-Packard 5880 gas chromatograph using a 3-m Porapak Q column heated isothermally at $100^{\circ} \mathrm{C}$. Carbon dioxide was analyzed using an O. I. Corporation Total Carbon System. Hydrogen and oxygen isotope analyses of hydrate water were provided by I. R. Kaplan at Global Geochemistry Corporation using standard procedures.

Metal and major cation analyses were performed using an Applied Research Laboratories (ARL) 34000 inductively coupled plasma emission spectrometer (ICP). The instrument is fitted with a PDP11/03-1 minicomputer that utilized SAS/ICP34 software, supplied by ARL, for data reduction. Fisher Scientific Company certified atomic absorption standards were used. Ion chromatography was performed using a Dionex 2110 Single Channel Ion Chromatograph. Concentrations of five anions $\left(\mathrm{F}^{-}, \mathrm{Cl}^{-}, \mathrm{Br}^{-}, \mathrm{NO}_{3}{ }^{-}\right.$, and $\left.\mathrm{SO}_{4}{ }^{2-}\right)$ and four cations $\left(\mathrm{Na}^{+}\right.$, $\mathrm{K}^{+}, \mathrm{Mg}^{2+}$, and $\mathrm{Ca}^{2+}$ ) were determined.

\section{OCCURRENCE OF GAS HYDRATES}

Kvenvolden and McDonald (this volume) summarize the occurrence of gas hydrates on Leg 84 . Briefly, gas hydrates were recovered from three sites $(565,568$, and 570 ). Most of the hydrate occurrences consisted of small amounts of white, icelike material that occupied fractures in mudstone and coarse-grained sediment. However, at Site 570, a massive hydrate (Section 570-27-1) measuring $1.05 \mathrm{~m}$ in length $(5.6 \mathrm{~cm}$ in diameter) was recovered at $249 \mathrm{~m}$ sub-bottom (1718 $\mathrm{m}$ water depth). This core is the first massive hydrate to be obtained in sea bottom sediments and the first to be preserved for laboratory studies. Sloan (this volume) reports on the preservation of this almost pure hydrate sample and some preliminary laboratory analyses. Downhole logs from this site indicate that this hydrate layer was 3 to $4 \mathrm{~m}$ thick.

\section{RESULTS AND DISCUSSION}

Kvenvolden and McDonald (this volume) report the shipboard measurements of gas from the decomposition of the gas hydrates. The average values from four analyses of a sample from Section 570-27-1 (the massive gas hydrate) are shown in Table 1. Laboratory measurements of the molecular composition of the gas from the decomposition of the preserved hydrate subsampled at the
Table 1. Comparison of hydrates recovered from sediments.

\begin{tabular}{|c|c|c|c|}
\hline & $\begin{array}{l}\text { Blake Outer } \\
\text { Ridge }^{2}\end{array}$ & $\begin{array}{l}\text { Middle America } \\
\text { Trench }{ }^{b}\end{array}$ & Gulf of Mexico \\
\hline Methane $(\%)$ & $36^{\mathrm{d}}$ & $61.3^{\mathrm{d}}$ & 67.5 \\
\hline Ethane $(\%)$ & 0.0123 & 0.14 & 4.5 \\
\hline Propane & $2 \mathrm{ppm}$ & $40 \mathrm{ppm}$ & $14.9 \%$ \\
\hline$i$-Butane & $2 \mathrm{ppm}$ & $18 \mathrm{ppm}$ & $4.2 \%$ \\
\hline$n$-Butane & $0.06 \mathrm{ppm}$ & $20 \mathrm{ppm}$ & $0.14 \%$ \\
\hline$C_{1} /\left(C_{2}+C_{3}\right)$ & $\sim 3000$ & 400 & 3.5 \\
\hline Carbon dioxide $(\%)$ & 0.5 & 0.3 & 3.9 \\
\hline${ }_{\delta^{13}} \mathrm{CC}_{1}$ (PBD) $\left(\%_{0}\right)$ & -68 & -41 to -44 & -45 \\
\hline${ }_{\delta}^{13} \mathrm{CC}_{2}$ (PBD) ( $\%$ ) & - & -27 & -29 \\
\hline${ }_{\delta}^{13} \mathrm{CO} 2$ (PBD) $\left(\%_{00}\right)$ & - & -2.9 & +13 to +19 \\
\hline$\delta \mathrm{DC}_{1}$ (SMOW) & - & - & - \\
\hline$\delta \mathrm{DH}_{2} \mathrm{O}$ (SMOW) (\%o) & - & +1 & - \\
\hline Water depth $(m)$ & 3184 & 1718 & $530-560$ \\
\hline Depth (sub-bottom) (m) & 238 & 249 & $0-5$ \\
\hline Gas: pore fluid ratios & $\sim 20: 1$ & $64-67: 1^{e}$ & $70: 1$ \\
\hline Chlorinity $(\% 0)$ & - & $0.65 \mathrm{f}$ & $9 \mathrm{~g}$ \\
\hline
\end{tabular}

${ }^{\text {a }}$ From Brooks, Barnard, et al. (1983).

b Samples are from Site 570; data are from this chapter and Kvenvolden and McDonald, this volume; molecular compositions are from the massive gas hydrate at Site 570 and represent the averages of four analyses; isotopic compositions represent the analysis of the hydrate from the samples stored at the Colorado School of Mines.

${ }^{c}$ From Brooks et al. (1984).

d Remainder of gas was atmospheric contamination.

e From Kvenvolden et al. (1983)

f Ionic salinity from Colorado School of Mines hydrate was $2.6 \%$.

$\mathrm{g}_{\text {Refractive index salinity. }}$

Colorado School of Mines confirmed the shipboard measurements that the hydrate sample from Section 570-271 was principally methane; its exact composition was $99.5 \%$ methane, $0.18 \%$ ethane, and $0.03 \% \mathrm{CO}_{2}$. Kvenvolden et al. (in press) report similar values but a higher amount of $\mathrm{CO}_{2}(\sim 0.4 \%)$. Small amounts of $\mathrm{C}_{3}-\mathrm{C}_{5}$ hydrocarbons $(<50 \mathrm{ppm})$ were also present in this hydrate gas.

The distribution of hydrocarbon gases indicates that the gas hydrate is primarily Structure I because only methane and ethane are present in significant concentrations. Evidence that little, if any, Structure II hydrate was present is indicated by the nearly identical concentrations of $i-\mathrm{C}_{4}$ and $n-\mathrm{C}_{4}$ in this hydrate gas. This observation contrasts with the results from the other two gas hydrate samples (Table 1) from the Northwest Atlantic and the Gulf of Mexico, which likely contained some Structure II hydrate having significantly higher concentrations of $i-\mathrm{C}_{4}$ compared with $n-\mathrm{C}_{4}$. However, the $i-\mathrm{C}_{4} /$ $n-\mathrm{C}_{4}$ ratio is maturity dependent, thus limiting its usefulness as an indicator of Structure II gas hydrate.

Table 2 shows isotopic ratios of the gas from the decomposing hydrate sampled at Site 570. Except for one sample $(-46.2 \%)$, the carbon isotopic ratios of $C_{1}$ ranged from about -41 to $-44 \% 0$ (relative to the PDB standard). These values are similar to those reported by Kvenvolden et al. (in press) from sequential degassing of the hydrate from Section 570-27-1 at the Colorado School of Mines. These variations likely result from variability in isotopic composition of the hydrate-bound methane and not from isotopic fractionation during sequential degassing. Brooks et al. (1983) showed that in hydrate from Leg 76 in the Blake Outer Ridge system there was little methane isotopic fractionation during hydrate decompositions. 
Table 2. Isotopic analysis of hydrate gas and water from Leg 84 .

\begin{tabular}{|c|c|c|c|c|c|c|}
\hline Section & ${ }_{\left({ }^{13}{ }^{13} \mathrm{C}_{\mathrm{C}_{1}}\right.}$ & ${ }_{\left({ }^{13} \mathrm{C}_{0}\right)}^{{ }^{13} \mathrm{C}_{2}}$ & ${ }^{\delta^{13}} \underset{\left(\gamma_{00}\right)}{\mathrm{C}_{2}}$ & $\begin{array}{l}\delta \mathrm{D} \\
\left(\%_{0}\right)\end{array}$ & $\begin{array}{l}\delta^{18} \mathrm{O} \\
\left(\%_{0}\right)\end{array}$ & Comment \\
\hline \multicolumn{7}{|l|}{ Gas } \\
\hline $570-27-1$ & -42.5 & $-^{b}$ & - & - & - & Metal vacutainer \\
\hline $570-27-1$ & -41.5 & - & - & - & - & Metal vacutainer \\
\hline $570-27-1$ & -42.3 & - & - & - & - & Metal vacutainer \\
\hline $570-27-1$ & -40.7 & - & - & - & - & Metal vacutainer \\
\hline $570-27-1$ & -42.0 & - & - & - & - & Metal vacutainer \\
\hline $570-27-1$ & -43.6 & - & - & - & - & SS cyclinder \\
\hline $570-27-1$ & -46.2 & - & - & - & - & SS cyclinder \\
\hline $570-27-1$ & -44.0 & -26.8 & -3.1 & - & - & Stored hydrate ${ }^{a}$ \\
\hline $570-27-1$ & -44.1 & -26.5 & -2.7 & - & - & Stored hydrate ${ }^{a}$ \\
\hline \multicolumn{7}{|l|}{ Water } \\
\hline $570-27-1$ & $\mathrm{na}^{\mathrm{b}}$ & na & na & $+1^{\mathrm{c}}$ & +2.2 & Cylinder water ${ }^{d}$ \\
\hline $570-27-1$ & na & na & na & +6 & $\begin{array}{l}+2.2 \\
+2.4\end{array}$ & Plastic bottle \\
\hline \multicolumn{7}{|c|}{$\begin{array}{l}\text { a Hydrate returned in a pressure vessel at low temperature and stored until December, } \\
\text { 1982, at the Colorado School of Mines, Golden, Colorado. A portion of the sample } \\
\text { at that time was collected in a stainless steel pressure vessel and allowed to decom- } \\
\text { pose in this closed vessel. } \\
\text { b na = not applicable; }-=\text { not determined. } \\
\text { c Global Geochemistry Corporation. } \\
\text { d Water from hydrate decomposition that decomposed and was stored in a closed stain- } \\
\text { less steel pressure vessel. } \\
\text { Water from hydrate decomposition in the shipboard laboratory that was collected and } \\
\text { stored in a closed plastic bottle. }\end{array}$} \\
\hline
\end{tabular}

Kvenvolden et al. (in press) and Kvenvolden and McDonald (this volume) have reported gas:pore fluid ratios ranging from 27:1 to 67:1 depending apparently on how soon after sampling the experiments were conducted. Similar ratios were found for the other deep ocean gas hydrates (Table 1) and reflect either gas loss during sampling or deviation from the ideal composition of methane hydrates.

The methane derived from the decomposing gas hydrate was similar to that obtained from void gases in sediments at Site 570 (Jeffrey et al., this volume). The void gases at Site 570 had isotopic ratios ranging from -60 to $-80 \%$ in the upper $205 \mathrm{~m}$ of the core, which is indicative of biogenic gas. Below these depths, methane isotopic values became rapidly heavier, reaching fairly constant values of -40 to $-45 \%$ at the bottom of the hole. The massive hydrate at Section 570-27-1 (249 m sub-bottom) was in the transition zone between 246 and $267 \mathrm{~m}$ where the void gases became heavier by $\sim 15 \%$. The isotopic values of -41 to $-44 \%$ for the hydrate gas are therefore similar to the void gases in this interval. This result is consistent with results from Leg 76 in the Blake-Bahama Outer Ridge area for which the isotopic composition of the hydrate obtained was similar to the void gas and pressure-core gas data (Brooks et al., 1983). Thus our results corroborate the results of Jeffrey et al. (this volume) and Brooks et al. (1983) and show that there is no apparent isotopic fractionation between the hydrate-bound methane and the free interstitial methane. This is expected because of the small molecular weight differences between ${ }^{13} \mathrm{C}$ - and ${ }^{12} \mathrm{C}$-containing methane.

Although the methane derived from the decomposing hydrate has an isotopic ratio characteristic of thermogenic methane (Kvenvolden and McDonald, this volume), the methane in this hydrate was most likely derived from in situ biogenic processes. Both the molecular composition of the gas and the difference between the isotopic compositions of coexisting $\mathrm{C}_{1}$ and $\mathrm{CO}_{2}$ support this conclusion. Jeffrey et al. (this volume) showed that at Site 570 between 205 and $395 \mathrm{~m}, \mathrm{C}_{1} / \mathrm{C}_{2}$ ratios averaged $\sim 970$, indicative of biogenic methane. The transition zone between 246 and $267 \mathrm{~m}$ where the methane becomes isotopically heavier is also accompanied by heavier $\mathrm{CO}_{2}$ (Jeffrey et al., this volume) and bicarbonate $\mathrm{CO}_{2}$ (Claypool et al., this volume). Because the isotopic profiles of $\mathrm{C}_{1}$ and $\mathrm{CO}_{2}$ parallel each other down the core the heavy methane likely results from bacterial reduction of $\mathrm{CO}_{2}$, with the bacteria using heavier $\mathrm{CO}_{2}$ in the deeper part of the hole. Rosenfeld and Silverman (1959) have shown that the fractionation effect from the bacterial production of $\mathrm{C}_{1}$ involves $\sim 70 \%$ so that bacterial processes using $\mathrm{CO}_{2}$ with a normal isotopic range of 15 to $+5 \%$ would likely produce biogenic methane of -85 to $-65 \%$. However, methane derived from bicarbonate with an isotopic ratio of about +30 to $+37 \%$, as measured by Claypool et al. (this volume), would be expected to produce methane near the $-40 \%$ value observed.

The source of the heavy $\mathrm{CO}_{2}$ in the core is only speculative. It could derive from a system in which the $\mathrm{CO}_{2}$ is being removed from the sediment by reduction to $\mathrm{C}_{1}$ and in which the addition of fresh, isotopically light $\mathrm{CO}_{2}$ from fermentation of organic matter is limited, therefore producing $\mathrm{CO}_{2}$ that becomes progressively heavier. It could also result from upward migration of thermal $\mathrm{CO}_{2}$, in which case the $-40 \% \mathrm{C}_{1}$ may result in part from thermogenic $C_{1}$. However, only small amounts of $\mathrm{CO}_{2}$ are present in the Site 570 gas hydrate as compared to the thermogenic gas hydrate from the Gulf of Mexico (Brooks et al., 1984). A complicating factor is that the $\mathrm{CO}_{2}$ from the Site 570 gas hydrate has an isotopic composition of $-2.9 \%$, which is not as heavy as the pore gas $\mathrm{CO}_{2}$ that increases from 0.3 to $10.7 \%$ in the interval between 246 and $267 \mathrm{~m}$. Although the $\delta^{13} \mathrm{CC}_{1}$ is more characteristic of the void gas at $267 \mathrm{~m}$ in the bottom portion of this sediment section, the $\delta^{13} \mathrm{CCO}_{2}$ is more characteristic of the void gas at $246 \mathrm{~m}$ in the upper portion of the section. Possible explanations for this discrepancy include (1) a fractionation between hydrated $\mathrm{CO}_{2}$ and nonhydrated $\mathrm{CO}_{2}$ (although the absence of methane fractionation in this process would argue against this mechanism), (2) fractionation in storage of the hydrate (the hydrated $\mathrm{CO}_{2}$ analysis was performed on the stored sample from the Colorado School of Mines [see Sloan, this volume]), (3) fractionation in sampling (the absence of methane fractionation in this stored sample would argue against this possibility), and more probably, (4) the incorporation of $\mathrm{CO}_{2}$ from different carbonate system reservoirs in the sediment section. It is possible that more hydrated $\mathrm{CO}_{2}$ originates from lighter, fermentation-produced, $\mathrm{CO}_{2}$ and that upwardly migrating thermal $\mathrm{CO}_{2}$ is contributing more to the reservoir of void gas $\mathrm{CO}_{2}$, which is heavier by 3 to $11 \%$.

The $\mathrm{C}_{2}$ in the Site 570 gas hydrate is probably derived from low-temperature diagenetic processes or possibly from upward migration of small amounts of thermogenic gas. The hydrated $\mathrm{C}_{2}$ isotopic compositions are 
consistent with the void gas $\delta^{13} \mathrm{CC}_{2}$ values reported by Jeffrey et al. (this volume). The $\delta^{13} \mathrm{C}_{2}$ values of void gases were fairly uniform from -24.2 to $-25.7 \%_{0}$ in six sections in the region of the gas hydrate. Ethane in the massive gas hydrate had a $\delta^{13} \mathrm{C}$ value of $-26.7 \%$. This isotopic value is surprisingly heavy, being heavier by $2 \% 0$ than the $\mathrm{C}_{2}$ from the thermogenic hydrate from the Gulf of Mexico. Jeffrey et al. (this volume) report that the isotopic values of ethane and propane in the void gases at Site 570 are among the heaviest reported and do not appear to fit the maturity trend for natural gases of marine-derived organic matter established by Stahl and Carey (1975) and Stahl (1977). In this trend, methane, ethane, and propane become progressively heavier with increasing maturity. Very immature gases, such as those associated with the shallow hydrate, appear to be much heavier than would be predicted. Jeffrey et al. (this volume) suggest that the heavy ethane observed in this study may result from a mechanism suggested by Chung and Sackett (1979) in which anomalously heavy gas could be produced by isotopic heterogeneity in precursor molecules with earliest formed hydrocarbons being generated from isotopically heavy regions of the precursor molecules.

The $\delta \mathrm{DH}_{2} \mathrm{O}$ values from two gas hydrate water samples from Site 570 were +1 and $+6 \%$, whereas the $\delta^{18} \mathrm{OH}_{2} \mathrm{O}$ of the same samples were +2.2 and $+2.6 \%$, respectively. The $\delta \mathrm{DH}_{2} \mathrm{O}$ values differ significantly from the value of $+18 \%$ reported by Sloan (this volume), whereas the $\delta^{18} \mathrm{OH}_{2} \mathrm{O}$ values are consistent with the value of $+2.0 \%$ given in Sloan (this volume). Not enough pore-water data are available to interpret the $\delta^{18} \mathrm{O}$ fractionation, although the $\delta^{18} \mathrm{OH}_{2} \mathrm{O}$ values are heavy compared to normal interstitial waters and may reflect oxygen isotope exchange with the heavy $\mathrm{CO}_{2}$ and bicarbonate reservoirs. Hesse and Harrison (1981) previously pointed out the $\delta^{18} \mathrm{OH}_{2} \mathrm{O}$ fractionation in waters associated with gas hydrates of the Middle American Trench.

Analyses of the hydrate water indicated a very low chlorinity for the massive hydrate at Site 570. Kvenvolden and McDonald (this volume) report that chlorinities for all the hydrate samples from Sites 565,568 , and 570 ranged from 0.5 to $3.2 \%$. Sloan (this volume) reports a salinity of $0 \%$ for the Site 570 gas hydrate, whereas we determined the salinity in an aliquot of water from the same gas hydrate to be $2.6 \%$. This value is consistent with the chlorinity of $0.65 \%$ measured by Kvenvolden and McDonald (this volume) on board ship. Most of the major ions (Table 3) are enriched relative to chloride as compared to normal seawater, with the exception of magnesium.

\section{SUMMARY}

Gas hydrates appear to be common in slope sediment of the Middle America Trench. Samples of hydrate have been observed in the area from Legs 66,67 , and 84 . The gas hydrate at Site 570, Leg 84, appears to be Structure I and is composed principally of water and methane. Although the carbon isotopic value for methane of about -41 to $-44 \%$ would itself be indicative of a deeper thermogenic methane source, the high $C_{1} / C_{2}$ ratios in
Table 3. Analysis of Section 570-27-1 hydrate water.

\begin{tabular}{|c|c|c|}
\hline Parameter & $\begin{array}{l}\text { Ion chromatography } \\
\text { (ppm) }\end{array}$ & $\begin{array}{l}\mathrm{ICP} \\
(\mathrm{ppm})\end{array}$ \\
\hline $\mathrm{F}^{-}$ & 0.15 & - \\
\hline $\mathrm{Cl}^{-}$ & 763 & - \\
\hline $\mathrm{Br}^{-}$ & 3.9 & - \\
\hline $\mathrm{NO}_{3}-$ & 0.37 & - \\
\hline $\mathrm{SO}_{4}{ }^{2-}$ & 801 & - \\
\hline $\mathrm{Na}^{+}$ & 730 & 710 \\
\hline $\mathrm{K}^{+}$ & 78 & 75 \\
\hline $\mathrm{Mg}^{2}+$ & 38 & 48 \\
\hline $\mathrm{Ca}^{2}+$ & 170 & 114 \\
\hline $\mathrm{Li}$ & - & 0.10 \\
\hline $\mathrm{Mn}$ & - & 0.21 \\
\hline Mo & - & 0.07 \\
\hline $\mathrm{Si}$ & - & 5.7 \\
\hline $\mathrm{Sr}$ & - & 1.0 \\
\hline B & - & 1.4 \\
\hline $\mathrm{Ba}$ & - & 0.17 \\
\hline $\mathrm{Bi}$ & - & 0.13 \\
\hline C & - & 407 \\
\hline $\mathrm{Fe}$ & - & 0.03 \\
\hline
\end{tabular}

both the hydrates and the void gases suggest a biogenic source for the methane. The heavy-carbon isotopic ratios of void gas $\mathrm{CO}_{2}$ and bicarbonate in the sedimentary section containing the hydrate support this. The heavy $\delta^{13} \mathrm{CC}_{2}$ results either from low-temperature diagenesis or upward migration of deeper thermogenic gas. The isotopic analysis of the hydrate gas is consistent with void gas analyses indicating there is apparently little fractionation between the hydrate-bound and interstitial methane.

\section{ACKNOWLEDGMENTS}

We thank the individuals of the Glomar Challenger for their help during the sampling procedures. Research support for this study was provided by Gas Research Institute Grant 5081-363-0460 and Office of Naval Research Grant N00014-80-C-0113. Instrumentation support for this project was provided by the Center for Energy and Mineral Resources at Texas A\&M University. Laboratory analysis of the interstitial water was provided by Scott Schofield, Benjy Cox, and Kathy Cole. We thank I. R. Kaplan at Global Geochemistry Corporation for the isotope analysis of the hydrate water. Comments by G. E. Claypool and D. A. Wiesenburg, the reviewers of this paper, are greatly appreciated.

\section{REFERENCES}

Brooks, J. M., Barnard, L. A., Wiesenburg, D. A., Kennicutt II, M. C., and Kvenvolden, K., 1983. Molecular and isotopic compositions of hydrocarbons at Site 533, DSDP Leg 76. In Sheridan, R. E., Gradstein, F. M., et al., Init. Repts. DSDP, 76, Washington (U.S. Govt. Printing Office), 377-390.

Brooks, J. M., Kennicutt II, M. C., McDonald, T. J., Fay, R. R., and Sassen, R., 1984. Thermogenic gas hydrates in the Gulf of Mexico. Science, 225:409-411.

Chung, H. M., and Sackett, W. M., 1979. Use of stable carbon isotope compositions of pyrolytically derived methane as maturity indices for carbonaceous materials. Geochim. Cosmochim. Acta, 43: 1979-1988.

Davidson, D. W., El-Defrawy, M. K., Fuglem, M. O., and Judge, A. S., 1978. Natural gas hydrates in northern Canada. Proc. Int. Conf. Permafrost 3rd, 1:937-943.

Hesse, R., and Harrison, W. E., 1981. Gas hydrate (clathrates) causing pore water freshening and oxygen isotopic fractionation in deepwater sedimentary sections of terrigenous continental margins. Earth Planet. Sci. Lett., 55:453-462. 
Kvenvolden, K. A., and Barnard, L. A., 1983a. Hydrates of natural gas in continental margins. Proc. Hedberg Conference: Tulsa (Am. Assoc. Pet. Geol.); pp. 631-640.

1983b. Gas hydrates of the Blake Outer Ridge Site 533, DSDP/IPOD Leg 76. In Sheridan, R. E., Gradstein, F. M., et al., Init. Repts. DSDP, 76: Washington (U.S. Govt. Printing Office), 353-366.

Kvenvolden, K. A., Claypool, G. E., Threlkeld, C. N., and Sloan, E. D., in press. Geochemistry of a naturally occurring massive marine gas hydrate. In Advances in Organic Geochemistry; 1983: London (Pergamon).

Kvenvolden, K. A., and McMenamin, M. A., 1980. Hydrates of natural gas: A review of their geologic occurrence. U.S. Geol. Surv. Circ., 825:1-11.

Moore, J. C., Watkins, J. S., Bachman, S. B., Beghtel, F. W., Butt, A., et al., 1979. Middle American Trench. Geotimes, 24(9):20-22.

Rosenfeld, W. D., and Silverman, S. R., 1959. Carbon isotopic fractionation in bacterial production of methane. Science, 130:1658-1659.

Sackett, W. M., Nakaparksin, S., and Dalrymple, D., 1970. Carbon isotope effects in methane production by thermal cracking. In Hobson, G. D., and Speers, G. C. '(Eds.), Advances in Organic Geochemistry, 1966: New York (Pergamon), 37-52.
Shipley, T. H., Houston, M. H., Buffler, R. T., Shaub, F. J., McMillan, K. J., Ladd, J. W., and Worzel, J. L., 1979. Seismic evidence for widespread possible gas hydrate horizons on continental slopes and rises. Am. Assoc. Pet. Geol. Bull., 63:2204-2213.

Stahl, W., 1977. Carbon and nitrogen isotopes in hydrocarbon research and exploration. Chem. Geol., 20:121-150.

Stahl, W., and Carey, B. D., 1975. Source rock identification by isotope analyses of natural gases from fields in the Val Verde and Delaware Basins, West Texas. Chem. Geol., 16:257-267.

von Huene, R., Aubouin, J., and Shipboard Scientific Party, 1980. Leg 67: the Deep Sea Drilling Project Mid-America Trench transect off Guatemala. Geol. Soc. Am. Bull., 91(1):421-432.

Yefremova, A. G., and Zhizhchenko, B. P., 1974. Obnaruzheniye kristal-ligradov gazov osadkakh sovremennykh akvatority. "Occurrence of crystal-hydrates of gases in the sediments of modern marine basins." Dokl. Akad. Nauk SSR, 214:1179-1181; Dokl. Akad. Nauk SSR, Earth Sci. Sect. (Engl. Transl.), 214(1975):219-220.

Date of Initial Receipt: 6 September 1983

Date of Acceptance: 20 November 1983 